\title{
THE GENUS GUERREROSTRONGYLUS (NEMATODA: HELIGMONELLIDAE) IN CRICETID RODENTS FROM THE ATLANTIC RAIN FOREST OF MISIONES, ARGENTINA: EMENDED DESCRIPTION OF GUERREROSTRONGYLUS ZETTA (TRAVASSOS, 1937) AND DESCRIPTION OF A NEW SPECIES
}

\author{
María Celina Digiani, Juliana Notarnicola*, and Graciela T. Navone* \\ División Zoología Invertebrados, Museo de La Plata. Paseo del Bosque s/n (1900) La Plata, Argentina. e-mail: mdigiani@fcnym.unlp.edu.ar
}

\begin{abstract}
Two species of Guerrerostrongylus Sutton and Durette-Desset, 1991, are reported in cricetid rodents from the Atlantic rain forest of Misiones, Argentina. Guerrerostrongylus zetta (Travassos, 1937) is redescribed on the basis of material collected from Oligoryzomys nigripes from Argentina and material loaned by CHIOC from Brazil. It is characterized by a synlophe with about $40-45$ (35-48) well-developed cuticular ridges, caudal bursa with long rays 6 and dorsal ray divided at mid-length, and well-sclerotized spicules with marked twisting. It was found with a prevalence of $100 \%$ in O. nigripes (14 hosts examined); however, it was not found in its type host Nectomys squamipes (4 hosts examined). Guerrerostrongylus ulysi n. sp., which is described from Sooretamys angouya, differs from the remaining species in the genus mainly by a synlophe with a strong reduction of the cuticular ridges and struts on the right side, and by a heart-shaped caudal bursa, with 6 short rays and a dorsal ray divided distally. It was found with a prevalence of $100 \%$ in 5 hosts examined.
\end{abstract}

The genus Guerrerostrongylus Sutton and Durette-Desset, 1991 (Trichostrongylina, Nippostrongylinae), is presently composed of 2 nominal species, i.e., the type species Guerrerostrongylus uruguayensis Sutton and Durette-Desset, 1991, described from Oligoryzomys flavescens (Waterhouse, 1837) (Cricetidae) in Uruguay (Sutton and Durette-Desset, 1991), and Guerrerostrongylus zetta (Travassos, 1937), described in a host referred to as "rato rapé" from Angra dos Reis, Estado do Rio, Brazil (Travassos, 1937). The latter species was subsequently reported in Brazil from at least 6 different host species (Pinto et al., 1982; Gomes et al., 2003, Simões et al., 2011).

Despite the numerous findings of G. zetta, the species has not been re-described, and its synlophe remained hitherto unknown. During a survey on parasites of cricetid rodents from the rain forest of Misiones, Argentina, specimens belonging to Guerrerostrongylus were found in 2 Oryzomyini: Sooretamys angouya (Fischer, 1814) and Oligoryzomys nigripes (Olfers, 1818). The parasites from $S$. angouya were recognized as a new species, which is described herein. The parasites from $O$. nigripes were identified as $G$. zetta, for which an emended description is provided.

\section{MATERIALS AND METHODS}

Twenty-three rodents belonging to 3 species (Sooretamys angouya, $\mathrm{n}=$ 5 , Oligoryzomys nigripes, $\mathrm{n}=14$, and Nectomys squamipes, $\mathrm{n}=4$ ) were examined. They were captured with Sherman traps at different localities: Reserva UNLP Valle del Arroyo Cuña Pirú (O. nigripes, $\mathrm{n}=13, N$. squamipes, $\mathrm{n}=1)$, Reserva Privada de Vida Silvestre Urugua-í $(O$. nigripes, $\mathrm{n}=1, S$. angouya, $\mathrm{n}=1$ ), Puerto Península, Parque Nacional Iguazú ( $S$. angouya, $\mathrm{n}=1$ ), Refugio Moconá, Reserva de la Biosfera Yabotí ( $S$. angouya, $\mathrm{n}=2, N$. squamipes, $\mathrm{n}=2$ ), and Reserva de Usos Múltiples Guaraní, Municipio El Soberbio $(S$. angouya, $\mathrm{n}=1, N$. squamipes, $\mathrm{n}=1$ ). The nematodes recovered were preserved in $70 \%$ ethanol. The synlophe was studied following the method of DuretteDesset (1985). Measurements are given in micrometers except where stated otherwise. Measurements for G. zetta are given as follows: mean value followed by range in parentheses. If fewer than 3 specimens were measured, then the range is given. For the new species, measurements of the types are given separated from those of the paratypes by semicolons

Received 28 December 2011; revised 4 April 2012; accepted 11 April 2012

* CEPAVE Centro de Estudios Parasitológicos y de Vectores, CCT La Plata, CONICET-UNLP, Calle 2 no. 584, (1900) La Plata, Argentina. DOI: 10.1645/GE-3075.1 paratype means are given with the range enclosed in parentheses. SpL/BL and UtL/BL mean the proportion (in percentage) of the spicule length on the body length and of the uterus length on the body length, respectively.

For comparative purposes, material identified as $G$. zetta from $O$. nigripes from Brazil was obtained on loan from the Helminthological Collection of the Instituto Oswaldo Cruz, Rio de Janeiro, Brazil (CHIOC), no. 35589. The parasite classification used above the family group level is that of Durette-Desset and Chabaud (1993), and the nomenclature of the hosts at the species level follows Wilson and Reeder (2005) and Weksler et al. (2006). Parasite specimens were deposited in the Helminthological Collection of the Museo de La Plata, La Plata, Argentina (CHMLP), and rodent specimens were deposited in the Mammal Collections of the Museo de La Plata, La Plata, Argentina (MLP); Centro Nacional Patagónico, Chubut, Argentina (CNP); and Museo Argentino de Ciencias Naturales, Buenos Aires, Argentina (MACN). Other rodents have field number JN.

\section{EMENDED DESCRIPTION}

\section{Guerrerostrongylus zetta (Travassos, 1937) Sutton and} Durette-Desset, 1991

(Figs 1-9)

General: Medium to large sized nematodes, uncoiled or irregularly coiled. Cephalic vesicle well developed. In apical view, triangular oral opening surrounded by thick ring; 2 amphids observed. Other papillae not seen. Excretory pore situated between $66 \%$ and $84 \%$ of esophagus length in males and between $75 \%$ and $81 \%$ in females. At esophagus level, conspicuous cuticular dilatation on left side, visible en toto and in transverse section.

Synlophe (studied in 4 males and 7 females): In both sexes, body bearing continuous cuticular ridges with chitinoid struts. Ridges appearing just posterior to cephalic vesicle and increasing in number mainly on left side up to esophago-intestinal junction, disappearing just anterior to caudal bursa in males and between vulva and anus in females. At level of distal esophagus: 29-30 ridges in male, 35-39 in female, all with chitinoid struts, mainly orientated from right to left in 2 divergent groups. At mid-body, ridges numerous, equidistant, all with chitinoid struts. Mean distance between ridges $15 \mu \mathrm{m}$. Right ridges slightly smaller than dorsal, ventral, and right ridges. Right, dorsal, and ventral ridges orientated from right to left in 2 divergent groups. Left ridges orientated perpendicularly to body surface. Axis of orientation subfrontal. Number of ridges variable in relation to body diameter, barely variable in males, from 40 to 44 ridges (Fig. 1); 

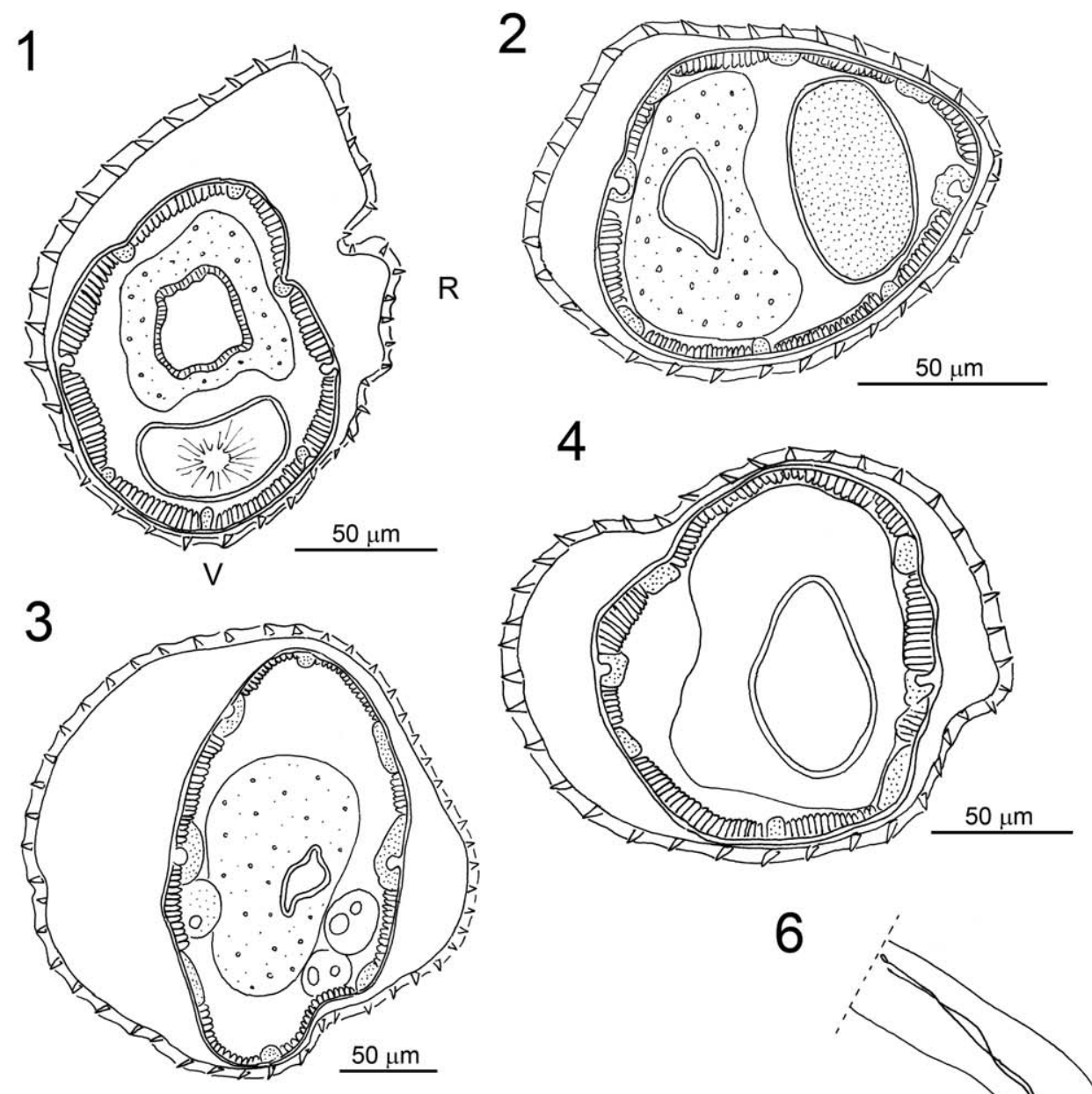

\section{9}
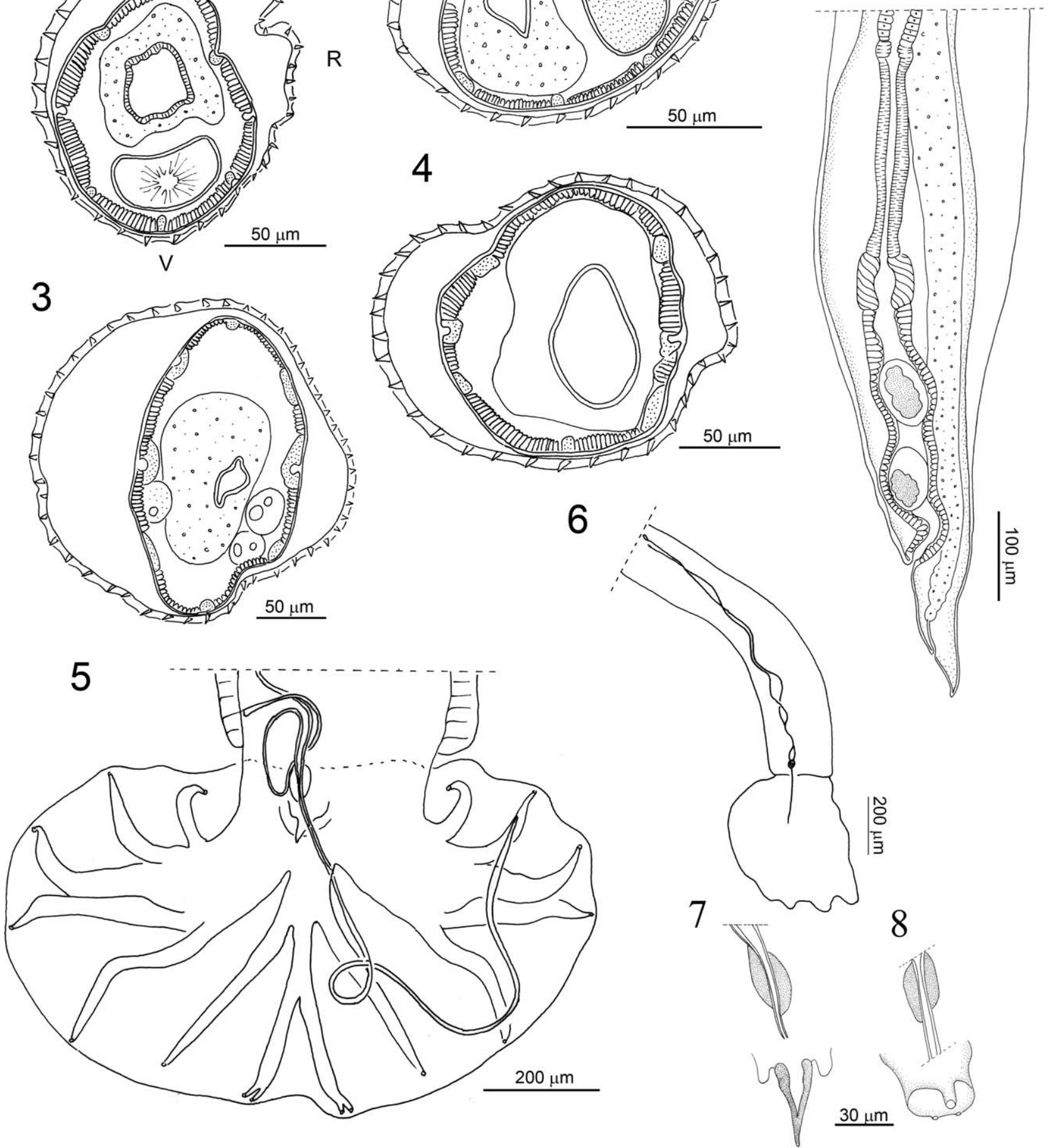

Figures 1-9. Guerrerostrongylus zetta (Travassos, 1937). (1-4) Transverse sections at mid-body. (1) Male, $6.55 \mathrm{~mm}$ long, 52\% of body length. (2) Female, $5.5 \mathrm{~mm}$ long and $130 \mu \mathrm{m}$ of body diameter, at $57 \%$ of body length. (3) Female, $11.7 \mathrm{~mm}$ long and $250 \mu \mathrm{m}$ of body diameter, at $50 \%$ of body length. (4) Male, $6.55 \mathrm{~mm}$ long, 88\% of body length. (5-8) Male. (5) Caudal bursa, ventral view. (6) Spicules in situ, left ventral view. (7) Telamon, gubernaculum, and tip of spicules. (8) Genital cone, ventral view. (9) Female, posterior extremity, left lateral view. Abbreviations: R, right, L, left. All sections orientated as Fig. 1. 
in females, number strongly variable, from 35 in female, $5.5 \mathrm{~mm}$ long, and 130 of body diameter, to 48 in female, $11.7 \mathrm{~mm}$ long, and 250 of body diameter (Figs. 2, 3). Similar to mid-body in number and orientation of ridges within posterior third of body length, chitinoid struts well developed (Fig. 4).

Males (based on 23 specimens): Body length 6.75 (4.40-8.40) $\mathrm{mm}$ and width at mid-body 197 (140-290); cephalic vesicle 56 (35$70)$ long and 44 (30-60) wide; nerve ring, excretory pore, and deirids situated 234 (190-295), 305 (250-345), and 315 (250-380) from apex, respectively; esophagus 401 (345-495) long. Caudal bursa sub-symmetrical, ellipsoidal, with dorsal lobe well developed and pattern of type 2-2-1 tending to 1-3-1 (Durette-Desset and Digiani, 2012). Rays 2 and 3 directed forwards, rays 2 shorter, curved inwards, not reaching bursal margin. Rays 4 slightly longer than rays 5 , both divergent at extremities, rays 4 directed forwards, rays 5 straight or slightly curved backwards. Rays 6 arising from common trunk of rays 4-6 proximal to rays 3 . Rays 6 long, reaching bursal margin. Rays 8 arising from proximal quarter of dorsal ray and shorter than it, not reaching bursal margin. Dorsal ray long, divided at about mid-length into 2 branches, each branch giving rise to 2 small branches, rays 9 (external branches) and rays 10 (internal branches) (Fig. 5). Spicules thin, well sclerotized, usually strongly twisted, 1,115 (750-1,420) long, with sharp tips (Fig. 6). Ratio SpL/BL: 16.7\% (9.8-21.6\%). Gubernaculum 36 (28-40) long and 19 (15-25) wide $(\mathrm{n}=5)$. Telamon well sclerotized, triangular (Fig. 7). Genital cone blunt, poorly developed. Papilla zero large and pedunculated on ventral lip, papillae 7 small and sessile on dorsal lip (Fig. 8).

Females (based on 27 specimens): Body length 9.17 (5.50-13.70) $\mathrm{mm}$ and width at mid-body 197 (100-290); cephalic vesicle 55 (35$65)$ long and 43 (35-60) wide; nerve ring, excretory pore, and deirids situated at 169 (130-285), 345-380, and 253 (235-275) from apex, respectively; esophagus 411 (350-500) long. Monodelphic. Vulva at 176 (112-255) from caudal extremity; vagina vera 21 (15-25), vestibule 232 (160-310) long, sphincter 52 (40-65) long and 52 (40-80) wide, infundibulum 225 (160-315) long; uterus 1,230 (800-1,560) long, containing 28 (6-50) eggs. UtL/BL $16.1 \%$ (9.5-22.4\%). Tail conical, 70 (40-100) long (Fig. 9). Eggs 55-72 long and 38-45 wide.

\section{Taxonomic summary}

Synonyms: Longistriata zetta Travassos, 1937; Hassalstrongylus zeta (Travassos, 1937) Durette-Desset, 1971; Guerrerostrongylus zeta (Travassos, 1937) Sutton and Durette-Desset, 1991.

Host: Oligoryzomys nigripes (Olfers, 1818) (Rodentia, Cricetidae, Sigmodontinae).

Site of infection: Small intestine.

Localities: Reserva UNLP Valle del Arroyo Cuña Pirú $\left(27^{\circ} 05^{\prime} 15^{\prime \prime} \mathrm{S}, 54^{\circ} 57^{\prime} 09^{\prime \prime} \mathrm{W}\right)$, Aristóbulo del Valle, Depto. Cainguás (MLP 6.XI.09.81, CNP 1869 (JN432), CNP 1883 (JN436), CNP 1802 (JN445), CNP 1859 (JN450), JN467, CNP 1887 (JN475), JN488, CNP 1820 (JN503), JN516, CNP 1886 (JN521), JN531, JN577), and Reserva Privada de Vida Silvestre Urugua-í (25⒌' $54^{\circ} 05^{\prime} \mathrm{W}$ ), Depto. General Manuel Belgrano (MACN 22.260), Misiones, Argentina.

Prevalence and mean intensity of infection: Prevalence 100\% (14 hosts examined); mean intensity 16.2 (range 1-78) worms per host.

Specimens deposited: From Cuña Pirú: CHMLP 6506 ( 7 males, 5 females), CHMLP 6507 (6 males, 6 females), CHMLP 6508
(5 males, 3 females), CHMLP 6509 (2 females), CHMLP 6510 (9 males, 5 females), CHMLP 6511 (1 male), CHMLP 6512 ( 2 females), CHMLP 6515 (6 males, 9 females), CHMLP 6516 (2 males, 5 females), CHMLP 6517 (5 males, 12 females), CHMLP 3508 (1 male). From Urugua-í: CHMLP 6518 (30 males, 43 females).

Additional material: CHIOC No. 35589 from Oligoryzomys nigripes, Brazil.

Co-parasitism: With the exception of host MACN 22.260, all the rodents examined harbored in the small intestine a second heligmonellid species, apparently assignable to Stilestrongylus, but still unidentified at the species level. One host (CHMLP 6510) also harbored specimens assignable to Trichofreitasia Sutton and Durette-Desset, 1991, probably Trichofreitasia lenti Sutton and Durette-Desset, 1991.

\section{Remarks}

Our specimens correspond well by morphometric and morphological characters to the species described by Travassos (1937) as Longistriata zetta. Travassos (1937) carefully described and illustrated characters as the shape and pattern of the caudal bursa, morphology of the spicules, gubernaculum, and telamon, all of which allow the identification of the present specimens to his species; however, he described the species as having about 16 longitudinal lines and 2 median alae. Though this description does not correspond to the synlophe described here, these alae can be probably interpreted as the cuticular dilatations, which are characteristic of the larger specimens, and which are supported by more cuticular ridges. The type material of L. zetta is deposited in the Helminthological Collection of the Instituto Oswaldo Cruz (CHIOC), Rio de Janeiro, Brazil. By a specific regulation of the CHIOC, the type material is not available on loan but only for en loco examination (M. Knoff, pers. comm.). For this reason, only voucher specimens of this species from $O$. nigripes from Brazil were obtained for examination. The specimens examined from the CHIOC also correspond to the description of Travassos (1937), and to the specimens studied here in all morphological characters, including the synlophe.

Longistriata zetta was transferred first to Hassalstrongylus by Durette-Desset (1971) and later to Guerrerostrongylus by Sutton and Durette-Desset (1991), even when its synlophe was unknown, mainly based on the characters of the caudal bursa and body size. The present description of the synlophe, characterized by a high number of cuticular ridges, subequal in size and mainly perpendicular to body surface at mid-body, therefore, confirms the inclusion of the species in Guerrerostrongylus as it was defined by Sutton and Durette-Desset (1991).

The original spelling zetta for the specific epithet is adopted here. The species was described by Travassos (1937) as Longistriata zetta, although in the illustrations the spelling zeta is utilized. Subsequent authors (Skrjabin et al., 1954; Mawson, 1961; Yamaguti, 1961; Durette-Desset, 1971; Sutton and DuretteDesset, 1991; Digiani et al., 2007) corrected the spelling to zeta. However, Singh (1967) claimed the validity of the original name zetta, arguing that, according to the International Code of Zoological Nomenclature (Stoll et al., 1961), incorrect transliteration or latinization are not to be considered inadvertent errors, and then they cannot be emended. The arguments of Singh (1967) are here revalidated, and based on the Article 32.5.1 of the 
International Code of Zoological Nomenclature (1999), the original name zetta is readopted.

\section{DESCRIPTION}

\section{Guerrerostrongylus ulysi n. sp.} (Figs. 10-21)

General: Medium sized nematodes, uncoiled or coiled irregularly. Cephalic vesicle well developed. In apical view, triangular oral opening surrounded by thick ring and 2 amphids observed. Other papillae no observed (Fig. 11). Excretory pore situated between 69\% and 83\% of esophagus length in males and between $54 \%$ and $67 \%$ in females. Deirids situated at same level as excretory pore or slightly posterior to it (Fig. 10). At esophagus level, conspicuous cuticular dilatation on the left, visible en toto and in transverse section.

Synlophe (studied in 3 males and 3 females, paratypes): In both sexes, body bearing longitudinal cuticular ridges appearing just posterior to cephalic vesicle, increasing in number mainly on left side within first third of body length. Ridges sensu stricto (salient ridges) disappearing at different levels of body length; right ridges from about mid-body and dorsal, ventral, and left ridges within distal third of body. At level of distal esophagus: 28-31 ridges in male, 28-33 in female, all with chitinoid struts. Right, dorsal, and ventral ridges orientated from right to left in 2 divergent groups. Left ridges orientated perpendicularly to body surface. Axis of orientation subfrontal (Figs. 12, 13). At mid-body: number of ridges variable in relation to body diameter. Less variable in males (42-44 ridges) where differences in size are less marked; more evidenced in females, which show a broader range of measurements (see below): 33-34 ridges in young female $5.5 \mathrm{~mm}$ long and 110 of body diameter, $40-46$ in females more than $1.0 \mathrm{~mm}$ long and $160-230$ of body diameter. Dorsal, ventral, and left cuticle bearing ridges with chitinoid struts, barely salient and mainly orientated perpendicularly to body surface. Dorsal and ventral struts slightly smaller than left ones. On right and right ventral sides: ridges absent and cuticle smooth (Figs. 14, 15); in some sections, struts absen (Fig. 14); in other sections, minute chitinoid struts present, not reaching nor projecting on the external surface (Fig. 15). Within posterior third of body length, similar to mid-body: dorsal and left cuticle practically without salient ridges, struts reaching irregularly the surface. On right and right ventral sides: cuticle smooth (Figs. 16, 17); in some sections, struts absent (Fig. 17); in other sections, minute chitinoid struts not reaching nor projecting on the external surface (Fig. 16). Right struts may be more developed at ovejector level in the female, but never projecting on the surface. Longitudinal rows of not projecting struts also visible en toto, disappearing just in front of the caudal bursa in male and between vulva and anus in female.

Males (based on holotype and 10 paratypes, except as indicated): Body length 7.00; $6.81(5.35-8.20) \mathrm{mm}$ and width at mid-body 200; 148 (130180); cephalic vesicle 75 ; 66 (60-72) long and 45; 45 (40-50) wide; nerve ring, excretory pore, and deirids situated at 210; 200 (165-240), 310; 299 $(250-340)(n=6)$, and $310 ; 314(280-330)(n=4)$ from apex, respectively; esophagus 410; 407 (380-450) long. Caudal bursa subsymmetrical, heartshaped, with dorsal lobe well developed and pattern of type 2-2-1 tending to 1-3-1 (Durette-Desset and Digiani, 2012). Rays 2 and 3 directed forwards, rays 3 slightly longer than rays 2 . Rays 4 longer than rays 5 , both divergent at extremities, rays 4 directed forwards, rays 5 straight. Rays 6 arising from common trunk of rays $4-6$ at same level than rays 3 or slightly proximal. Rays 8 arising from proximal quarter of dorsal ray and shorter than it. Dorsal ray long, divided at about distal quarter into 2 branches, each branch giving rise to 2 small branches, rays 9 (external branches) and rays 10 (internal branches) (Fig. 18). Spicules thin, poorly chitinized and sometimes difficult to observe, 530; 551 (455-665) long, with sharp tips. SpL/BL: 7.6\%; 8.2 (6.4-9.5)\%. Gubernaculum present, hardly visible, $25 ; 29(25-32)$ long and $12 ; 15(15-15)$ wide $(\mathrm{n}=3)$ Telamon absent. Genital cone rather poorly developed, 40; 54 (40-65) long and 30; $40(35-45)$ wide at base $(\mathrm{n}=4)$. Papilla zero not observed, but papillae 7 visible on dorsal lip (Fig. 19).

Females (based on allotype and 14 paratypes, except indication): Body length $12.25 ; 10.96(5.50-13.10) \mathrm{mm}$ long and width at mid-body $200 ; 182$ (110-250). Larger females ( $>10 \mathrm{~mm}$ long), usually very opaque and internal organs difficult to observe even after long diaphanization. Cephalic vesicle 70; 63 (50-72) long and 45; 45 (35-50) wide; nerve ring, excretory pore, and deirids situated at 190; $178(145-200)(\mathrm{n}=8), 255 ; 289$ $(235-310)(\mathrm{n}=7)$, and $255 ; 286(245-320)(\mathrm{n}=6)$ from apex, respectively; esophagus 460; 438 (370-550) long. Monodelphic. Vulva at 215; $212(110$ $250)$ from caudal extremity $(\mathrm{n}=10)$; vagina vera $25 ; 24(15-30)(\mathrm{n}=5)$, vestibule $120 ; 127(100-160)$ long $(n=11)$, sphincter $50 ; 46(40-50)$ long and 40; 45 (40-50) wide ( $\mathrm{n}=11)$, infundibulum 240; 203 (165-240) long (n $=5)$; uterus 2,$100 ; 1,960(600-2,800)$ long, containing $145,117(20-170)$ eggs. UtL/BL $17.1 ; 17.7$ (10.9-24.3)\%. Posterior extremity straight or slightly curved ventrally at vulvar level, then dorsally at level of anus (Fig. 20). Tail conical, 45; 44 (40-50) long $(\mathrm{n}=11)$ (Fig. 20). Six of 26 females observed (allotype, 3 paratypes, and 2 vouchers) had a vulvar cork, 200; 123 (30-210) long and 40; $27(10-40)$ thick (Fig. 21). Eggs 72-75 $(65-80)$ long by $50(38-50)$ wide.

\section{Taxonomic summary}

Type host: Sooretamys angouya (Fischer, 1814) (Cricetidae, Sigmodontinae) (MACN 22.263).

Site of infection: Small intestine.

Type locality: Reserva Privada de Vida Silvestre Urugua-í (25⒌'S, $\left.54^{\circ} 05^{\prime} \mathrm{W}\right)$, Depto. General Manuel Belgrano, Misiones, Argentina.

Other hosts and localities: One Sooretamys angouya from Puerto Península, Parque Nacional Iguazú $\left(25^{\circ} 40^{\prime} \mathrm{S}, 54^{\circ} 38^{\prime} \mathrm{W}\right)$, Depto. Iguazú (MLP 24.VIII.00.4). Two S. angouya from Refugio Moconá, A ${ }^{\circ}$ Oveja Negra y Ruta 2, Reserva de la Biosfera Yabotí $\left(27^{\circ} 08^{\prime} \mathrm{S}, 53^{\circ} 55^{\prime} \mathrm{W}\right)$, Depto. Guaraní (CNP 2524, CNP 2525), and 1 S. angouya from Reserva de Usos Múltiples Guaraní, Municipio El Soberbio $\left(26^{\circ} 55^{\prime} \mathrm{S}, 54^{\circ} 12^{\prime} \mathrm{W}\right)$, Depto. Guaraní, (CNP 2529), Misiones, Argentina.

Prevalence and mean intensity: Prevalence 100\% (5 hosts examined); mean intensity 19.6 (range 2-45) worms per host.

Type material: Holotype male CHMLP 6519, allotype female CHMLP 6520, 30 paratypes (13 males, 17 females) CHMLP 6521

Other material deposited: CHMLP 6523 (1 male, 1 female) and CHMLP 6524 (10 males, 20 females) from Moconá; CHMLP 6525 (2 males) from El Soberbio.

Etymology: The specific name ulysi is dedicated to Dr. Ulyses F.J. Pardiñas, a young and recognized mammalogist from Argentina, a specialist on the systematics of Neotropical rodents, also our colleague and friend.

Co-parasitism: Four of the hosts examined harbored in the small intestine other heligmonellid species (from 1 to 3), all assignable to the Nippostrongylinae ( 3 species in CNP 2524; 1 species in CNP 2525 and MLP 24.VIII.00.4, 2 species in CNP 2529). These species are still unidentified at the genus level, their identification depending on the quantity and quality of the specimens available.

\section{Remarks}

Specimens parasitizing S. angouya correspond to a species of Guerrerostrongylus as defined by Sutton and Durette-Desset (1991) by their large body size, the high number of cuticular ridges, subequal in size and mainly perpendicular to body surface at mid-body, and the caudal bursa with dorsal lobe hypertrophied.

These specimens show a particular synlophe in which the salient ridges (ridges sensu stricto), first on the right side and then on the rest of the body diameter, decrease in height from about mid-body, and finally disappear. However, most of their intracuticular struts persist. The rows of persistent intracuticular struts are also visible en toto, through the cuticle, giving the appearance of "true" ridges all along the body. By these reason, and in order to facilitate the comparison with other species in the genus, they account for the total number of ridges

The struts on the dorsal, ventral and left sides are always present and well visible, but within the distal third of body length they reach irregularly the surface and are usually not salient. On the right side, on the second half of the body, the cuticle is smooth; in some sections minute intracuticular projections never reaching the external surface are still visible in the positions corresponding to the ridges just disappeared. In other sections, at a similar body level, the struts are also absent. The exact level of the disappearance of the ridges sensu stricto and the extent of the development of the remaining struts varies with the specimens.

A similar condition was previously described in the type species $G$. uruguayensis, where, from about $500 \mu \mathrm{m}$ in front of the caudal bursa in male, and on the posterior cuticular inflation in the female, the struts ("arêtes" in the original French text) do not project on the body surface. 


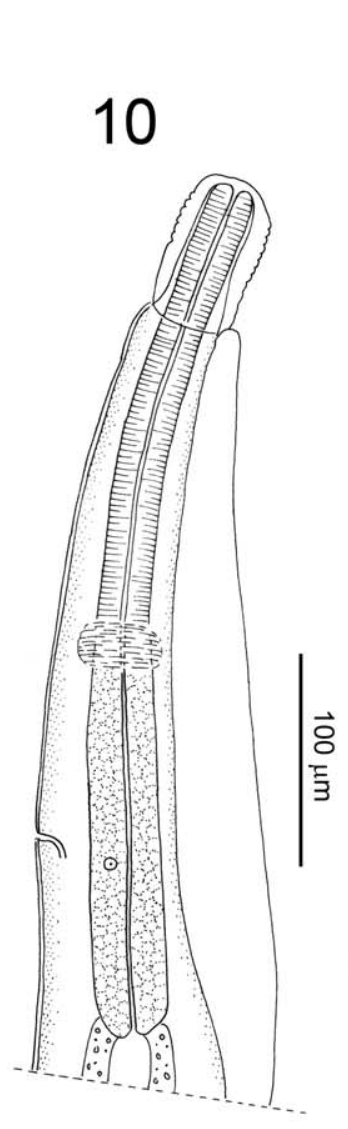

11

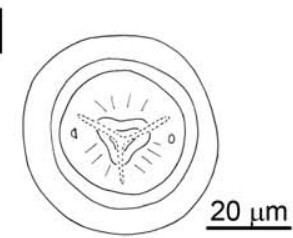

14

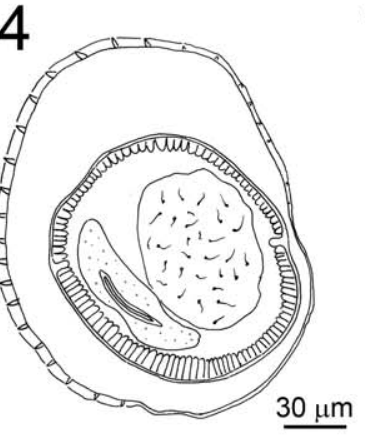

17

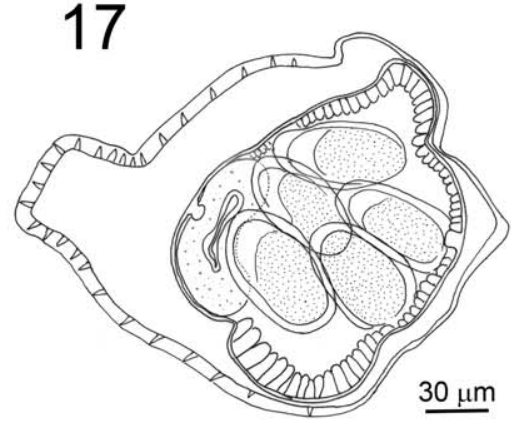

12

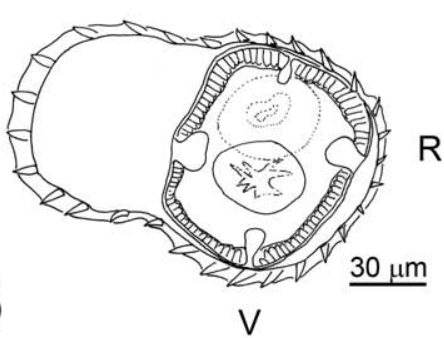

15

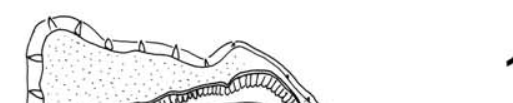

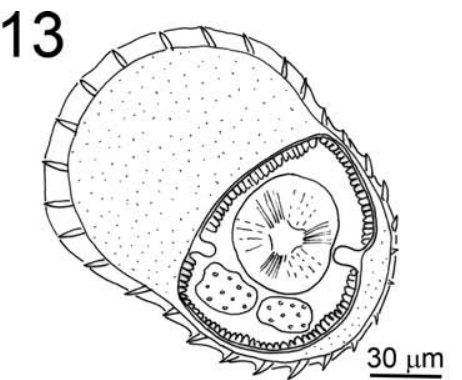

16

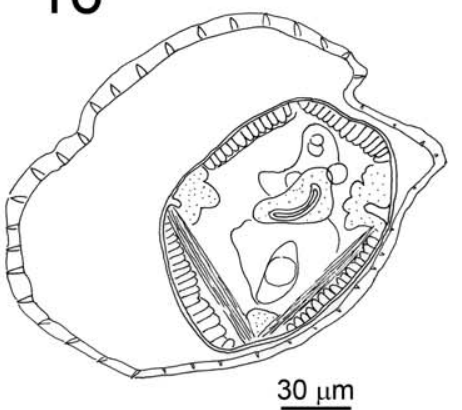

|

19
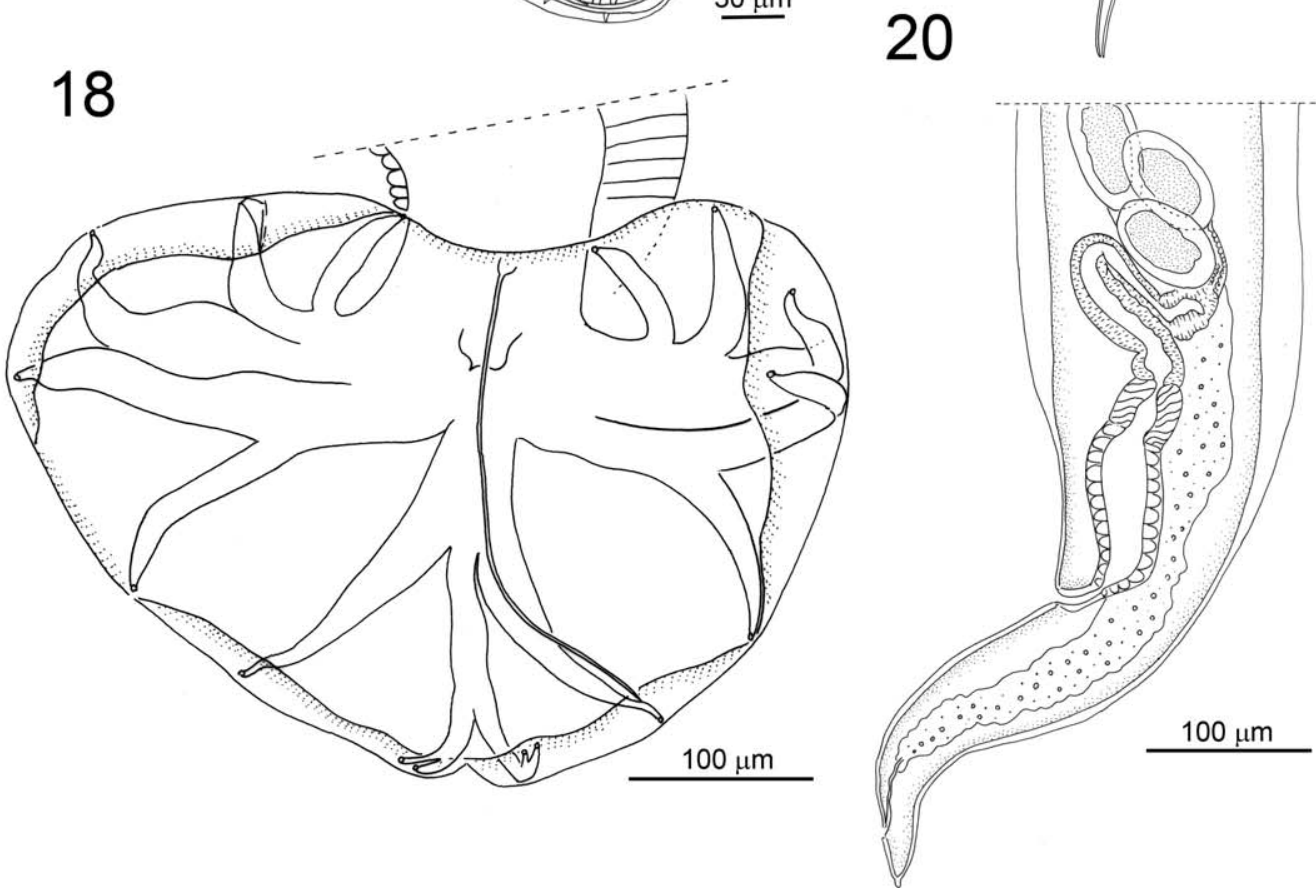

21
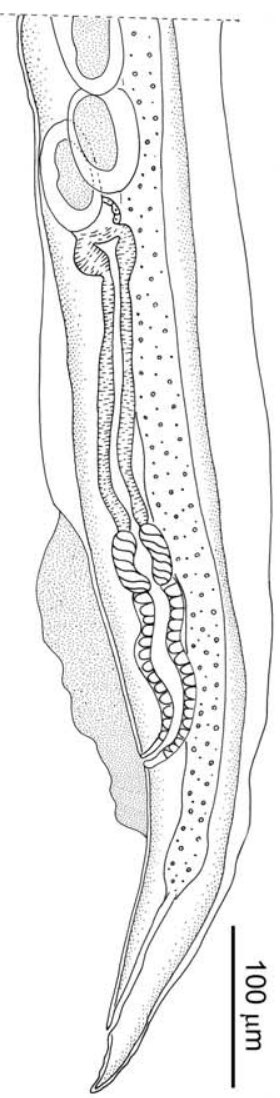

FIgUREs 10-21. Guerrerostrongylus ulysi n. sp. (10) Anterior extremity, left lateral view. (11) Female, head, apical view. (12-17) Transverse sections of the body. (12,13) At esophagus level. (12) Male, $400 \mathrm{~mm}$ from apex. (13) Female, $450 \mathrm{~mm}$ from apex. (14, 15) At mid-body. (14) Male, 50\% of body length. (15) Female, 55\% of body length. $(16,17)$ Within posterior part of body. (16) Male, 300 um in front of caudal bursa. (17) Female, at first third of uterus length ( $85 \%$ of body length). (18) Male, caudal bursa, ventral view. (19) Male, genital cone, gubernaculum, and tip of spicules. (20) Female without vulvar cork, posterior extremity, left lateral view. (21) Female with vulvar cork, posterior extremity, left lateral view. Abbreviations: R, right, L, left. All sections orientated as Fig. 12. 
The authors ignored if this condition was a specific character or an artifact due to the fixation (Sutton and Durette-Desset, 1991). Interestingly, these "not projecting" struts, which are well developed, are evident only on side of the transverse body sections, though this is not mentioned in the text. Figure 1J of G. uruguayensis represents the "not projecting" struts on the right side, whereas Figure $1 \mathrm{~L}$ represents these struts on the left side. We consider that Figure 1L of Sutton and Durette-Desset (1991) is not correctly orientated and that the "not projecting" struts of G. uruguayensis may be interpreted as homologous to the right struts of the specimen studied here. These non-projecting struts can be, therefore, confirmed as a valid character, present hitherto in 2 of the 3 described species of Guerrerostrongylus.

Guerrerostrongylus ulysi n. sp. differs, however, from G. uruguayensis by the strong reduction of the right struts in the second half of the body length, by the heart-shaped caudal bursa, with dorsal ray hypertrophied and longer than rays 6 , rays 6 shorter than rays 8 , spicules shorter, and a lesser SpL/BL (6.4-9.5\% versus $12.1 \%$ ). It also differs from $G$. zetta by the larger body size of the females, the shape of the caudal bursa (heartshaped versus ellipsoidal in $G$. zetta), the dorsal ray bifurcated at its distal third, spicules straight and weakly sclerotized (well sclerotized and markedly twisted in G. zetta), the lesser SpL/BL ( $G$. zetta: $13.7 \%$ in the original description, mean $16.7 \%$ in the present redescription), and the strong reduction of the ridges and struts of the synlophe in the second half of the body length ( $G$. zetta: synlophe with 35-48 ridges, well developed all along the body length, after the present redescription).

The females of the new species also differ from females identified as Guerrerostrongylus sp. described from Akodon simulator (Thomas, 1816 (Cricetidae) in Tucumán, Argentina (Digiani et al., 2007), by the reduction of the ridges and struts of the synlophe (Guerrerostrongylus sp.: 49-56 ridges with well-developed struts) and by the shape of the caudal extremity (straight and with cuticular inflations in G. ulysi, twisted $90^{\circ}$ to the righ and without cuticular inflations in Guerrerostrongylus sp.) (Digiani et al., 2007)

\section{DISCUSSION}

The finding of 2 different species of Guerrerostrongylus in Misiones (Argentina) enlarges the known geographic and host distribution for the genus, with $S$. angouya representing a new host record.

The host-parasite relationships and geographic distribution of species of Guerrerostrongylus are still not clearly established since the genus has been described recently and only 3 nominal species have been described. On the other hand, some of the records that are not accompanied by minimal descriptions or illustrations should require confirmation

Guerrerostrongylus ulysi n. sp. was until now only found in Sooretamys angouya from Misiones. The type species, $G$ uruguayensis, was until now reported in Oligoryzomys flavescens from Uruguay and in Akodon simulator from Tucumán (Northwest Argentina), though data regarding prevalences and intensities of infection are unknown (Sutton and Durette-Desset, 1991; Digiani et al., 2007).

Guerrerostrongylus zetta seems until now as the species of Guerrerostrongylus with broadest host and geographical range. In the original description of the species from Angra dos Reis, Estado do Rio (Brazil), Travassos (1937) referred to the host as "rato rape," without a specific name. However, available information from the CHIOC indicates that the type series was harbored in Nectomys squamipes (Brants, 1827) (Cricetidae) (M. Knoff, pers. comm.). Subsequently, the species was reported in Brazil from the Goiás and Bahia states in $N$. squamipes, Cerradomys subflavus (Wagner, 1842) (identified as Oryzomys subflavus), Oligoryzomys nigripes (Olfers, 1818) (partially identified as Oryzomys eliurus or Oligoryzomys eliurus) (Cricetidae), and Galea spixii (Wagler, 1831) (Caviidae) (Pinto et al., 1982).
Numbers for prevalence or intensities of infection in these hosts were not provided.

The species was also reported from the Brazilian Atlantic Forest of Rio de Janeiro in Euryoryzomys russatus (Wagner, 1848) (identified as Oryzomys intermedius), Akodon cursor Winge, 1887, and Oligoryzomys nigripes (Cricetidae) (Gomes et al., 2003; Simões et al., 2011), with the following values of prevalence and mean intensity: E. russatus, $\mathrm{P}=54.5 \%, \mathrm{MI}=45.7(\mathrm{n}=11)$ (Gomes et al., 2003); A. cursor, P $=28 \%, \mathrm{MI}=17.6(\mathrm{n}=14)$ (Gomes et al., 2003) and $\mathrm{P}=4 \%, \mathrm{MI}=1(\mathrm{n}=18)$ (Simões et al., 2011); O. nigripes, $\mathrm{P}=57.1 \%, \mathrm{MI}=10.7(\mathrm{n}=$ not specified $)$ (Gomes et al., 2003) and $\mathrm{P}=21.4 \%, \mathrm{MI}=30.8(\mathrm{n}=56)$ (Simões et al., 2011). In the present study the prevalence of G. zetta among O. nigripes was $100 \%$, with $\mathrm{MI}=16.2(\mathrm{n}=14)$ from 2 different localities of the Misiones rain forest.

It is interesting to note that even when $N$. squamipes is indicated as the type host of G. zetta, Gomes et al. (2003) examined $25 \mathrm{~N}$. squamipes from the Brazilian Atlantic Forest in the Rio de Janeiro state, with negative results for $G$. zetta, and similar results were obtained during this work, on 4 specimens of $N$. squamipes from 3 different localities from the Misiones rain forest.

The values accounted above show that $G$. zetta is undoubtedly one of the dominant species of the helminth community of $O$. nigripes, and that it is also a main component of the helminth community of $A$. cursor and E. russatus (see also Simões et al., 2011). In contrast, the status of its association with $N$. squamipes requires confirmation, but it seems to be rather occasional, or at least less frequent.

Co-parasitism within species of Guerrerostrongylus seems not to be frequent. In the present study and in those by Brazilian authors involving several hosts examined (Pinto et al., 1982; Gomes et al., 2003; Simões et al., 2011), each host species studied was parasitized by only 1 species of Guerrerostrongylus. A particular case is that of the females identified as Guerrerostrongylus sp. found in Akodon simulator from Tucumán (northwest Argentina). They showed a synlophe with 49-56 ridges well developed and the tail twisted $90^{\circ}$ to the right, but in the absence of other diagnostic characters, due to the opacity of the specimens, they could not be identified to or excluded from any of the known species of the genus (Digiani et al., 2007). Males of G. uruguayensis were identified from the same host species in the same work (Digiani et al., 2007), and it is likely that those females correspond actually to G. uruguayensis. However, these identifications were made on deposited material with insufficient collection data on the hosts examined and their individualization. The presence of 1 or 2 different species of Guerrerostrongylus in A. simulator will be confirmed only with the examination of newly collected material from several individual hosts.

\section{ACKNOWLEDGMENTS}

Thanks are due to J. Pereira and P. Beldomenico for collecting the hosts and parasites from Urugua-í; to A. Abba for collecting those from Puerto Península; to U. Pardiñas, D. Udrizar Sauthier (from CENPAT), C Galliari, M. del R. Robles, M. Lareschi, L. Zonta (from CEPAVE), and R. Almagro for helping during the fieldwork; to espicially U. Pardiñas, D. Udrizar Sauthier, and C. Galliari for the identification of the hosts. Dr. Marcelo Knoff, Curator of the CHIOC, kindly provided on loan voucher specimens of G. zetta. We thank María Cristina Estivariz (from CEPAVE) for the inking of the drawings. Material collected from Cuñá Pirú was funded by PICT 33816 (to J.N.) from ANPCYT; and that from Moconá by PICT 33019 (to G.T.N.). This study was supported by PIP 0006 (to 
M.C.D.) from CONICET and grants 11/N603 (to M.C.D.) and 11/N627 (to G.T.N.) from SECYT, UNLP.

\section{LITERATURE CITED}

Digiani, M. C., G. T. Navone, and M. C. Durette-Desset. 2007. The systematic position of some Nippostrongylinae (Nematoda: Trichostrongylina: Heligmosomoidea) parasitic in Argentinean sigmodontine rodents. Systematic Parasitology 67: 87-92.

Durette-Desset, M. C. 1971. Essai de classification des Nématodes Héligmosomes. Corrélation avec la paléobiogéographie des hôtes. Mémoires du Muséum national d'Histoire naturelle, nouvelle série, série A, Zoologie 49: 1-126.

. 1985. Trichostrongyloid nematodes and their vertebrate hosts: reconstruction of the phylogeny of a parasitic group. Advances in Parasitology 24: 239-306.

, AND A. G. Chabaud. 1993. Note sur la nomenclature suprafamiliale des Strongylida. Annales de Parasitologie Humaine et Comparée 68: $11-12$.

, AND M. S. Digiani. 2012. The caudal bursa in the Heligmonellidae (Nematoda : Trichostrongylina). Characterization and hypothesis on its évolution. Parasite 19: 3-18.

Gomes, D. C., R. P. Cruz, J. J. Vicente, and R. M. Pinto. 2003. Nematode parasites of marsupials and small rodents from the Brazilian Atlantic Forest in the State of Rio de Janeiro, Brazil. Revista Brasileira de Zoologia 20: 699-707.

ICZN (INTERNATIONAL COMmission ON ZoOlogical NomenClature). 1999. International code of zoological nomenclature, 4th ed. International Trust for Zoological Nomenclature, London, U.K., 306 p.

Mawson, P. M. 1961. Trichostrongyles from rodents in Queensland, with comments on the genus Longistrata (Nematoda: Heligmosomatidae). Australian Journal of Zoology 9: 791-826.
Pinto, R. M., A. Kohn, B. M. M. Fernandes, and D. A. Mello. 1982. Nematodes of rodents in Brazil, with description of Aspidodera vicentei $\mathrm{n}$. sp. Systematic Parasitology 4: 263-267.

Simões, R. O., J. G. R. Souza, A. Maldonado, JR., and J. L. LuQue. 2011. Variation in the helminth community structure of three sympatric sigmodontine rodents from the coastal Atlantic Forest of Rio de Janeiro, Brazil. Journal of Helminthology 85: 171-178.

Singh, K. S. 1968. Longistriata indica sp. n. (Heligmosomatidae: Trichostrongyloidea: Nematoda) from a hare from India. Proceedings of the National Institute of Sciences of India 35: 53-59.

Skrjabin, K. I., N. P. Schikhobalova, and R. S. Schulz. 1954. Principles of nematodology. In Dictyocaulidae, Heligmosomatidae, and Ollullanidae of animals, vol. IV, K. I. Skrjabin (ed.). Izdat Akademii Nauk, Moscow, SSSR, p. 1-323.

Stoll, N. R., R. P. Dollfus, J. Forest, N. D. Riley, C. W. Sabrosky, C. W. Wright, AND R. V. Melville. 1961. International Code of Zoological Nomenclature adopted by the XV International Congress of Zoology. International Trust for Zoological Nomenclature, London, U.K., $176 \mathrm{p}$.

Sutton, C. A., And M. C. Durette-Desset. 1991. Nippostrongylinae (Nematoda-Trichostrongyloidea) parasites d'Oryzomys flavescens en Argentine et en Uruguay. Revue Suisse de Zoologie 98: 535-553.

Travassos, L. 1937. Revisão da familia Trichostrongylidae Leiper, 1912. Monografias do Instituto Oswaldo Cruz 1: 1-512.

Wekssler, M., A. R. Percequillo, and R. S. Voss. 2006. Ten new genera of Oryzomyine Rodents (Cricetidae: Sigmodontinae). American Museum Novitates 3537: 1-29.

Wilson, D. E., And D. A. M. Reeder. 2005. Mammal species of the world. A taxonomic and geographic reference, 3rd ed. Johns Hopkins University Press, Baltimore, Maryland, $2142 \mathrm{p}$.

Yamaguti, S. 1961. Systema helminthum. The nematodes of vertebrates. Vol. III. Interscience Publishers, London, U.K., 1261 p. 
Authors Queries

Journal: The Journal of Parasitology

Paper: para-98-05-20

Title: THE GENUS GUERREROSTRONGYLUS (NEMATODA: HELIGMONELLIDAE) IN CRICETID RODENTS FROM THE ATLANTIC RAIN FOREST OF MISIONES, ARGENTINA: EMENDED DESCRIPTION OF GUERREROSTRONGYLUS ZETTA (TRAVASSOS, 1937) AND DESCRIPTION OF A NEW SPECIES

Dear Author

During the preparation of your manuscript for publication, the questions listed below have arisen. Please attend to these matters and return this form with your proof. Many thanks for your assistance

\begin{tabular}{|l|l|l|}
\hline $\begin{array}{l}\text { Query } \\
\text { Reference }\end{array}$ & Query & Remarks \\
\hline 1 & $\begin{array}{l}\text { Author: This article has been lightly } \\
\text { edited for grammar, style, and } \\
\text { usage. Please compare it with your } \\
\text { Original document and make any } \\
\text { corrections on these pages. Please } \\
\text { limit your corrections to substantive } \\
\text { changes that affect meaning. If no } \\
\text { change is required in response to a } \\
\text { question, please write "OK as set" } \\
\text { in the margin. CE }\end{array}$ & \\
\hline
\end{tabular}

